\title{
IDENTITY AT CROSSROAD: AN ASSESSMENT OF CHARACTERS' FEELINGS AND OBSERVATIONSIN SUNIL BHATIA'S AMERICAN KARMA
}

\author{
Baburam Khanal, PhD*
}

\begin{abstract}
In recent years, scholars working in different array of humanities and other disciplines have taken intense interest in question concerning about identity. Students studying in postgraduate and undergraduate levels have devoted much of their research in identity politics of race, culture, gender, language and nationality. Hence, the term identity is not limited to one or two definitions, but it needs multiple explanations, plurality in interpretation and on top of that it demands heterogeneous elucidation, and through research.
\end{abstract}

Keywords: Diaspora, Divided Loyalty, Identity, Globalization, Localization

Identity is a recent social construct with vague ideas. Even though everybody knows how to use the term identity properly in every day discourse, and how identity is in crisis. It is difficult to give a short and adequate summary that grabs the range of its present meaning. Prima facie, it is a catch word in globalized, techno oriented contemporary world. This article tries to observe and analyze i) how identity is at crossroad ii) what are its varied paradigms?

Harkening back to its root, the English word identity is derived from the Latin word idem which means the same. This term implies not only to some sort of intransience and stability which is crucial to being a subject but also applies to certain entities which are supplied with self awareness and ability to develop and learn (Fornas 232).

The issue of identity is central to the contemporary study of culture and literature. Culture study focuses on how we come to be the kind of people we are, and how we comply with identification of ourselves as male or female; black or non-black. According to Edgar and Sedwick, in cultural study, we examine the content with which and through which both individuals and group construct, negotiate and defend their identities" (183) Seen through the spectacles of cultural, identities are not concrete things, rather they are discursive constructions, the product of dominant discourses or regulated ways of speaking about the. Hence, identities are constituted categories. On the other hand, identity as a cultural product is mostly linked with ethnicity, class, race, sexuality and sub cultures. However, the intent to remain within an indigenous culture and land is challenged by the ongoing trend of localisation and migration to people's needs, urges and whims of settling in foreign lands. The concept that the migration process has shrunk the boundaries among the cultures and contemporary identities are, therefore, unconsciously rendered, fluid, feeble and tantamount to loss.

Associate Professor of Saraswati Multiple Campus (Humanities Faculty: English Department), Tribhuvan University, Nepal. 
Cornel West emphasizes the significance of identity connecting in to the precautions of life and death. West observes that identity as about desire and death, that is, how human beings construct their identity is based on how they conceive of death or how they want to have and die. Edward Said agrees that all the subtleties of life- like desire for recognition, visibility, are to be acknowledged and a deep desire for association come inside its frame (15). For West, it is the longing to belong, a deep primal need for human beings for which they negotiate with their environments. Through identity, as West, writes, they have deep desire for protection, security, safety, and surely" (16) Thus, identity does not only gives life and sense of security of the individual but also it protects their culture, their land and history.

Most significantly, an individual feels secure and comfortable within the particular culture and society which gives him a firm identity. The people expatriated to the land other than their own suffer from the sense of alienation and dislocation in the lack of identity. So, the expatriated writers, generally known as diasporic writers, express the trauma and miseries in the migrated land as they feel that their identity is in crisis devoid of which it is difficult to lead a lively life.

\section{Diasporic Identity}

When the migration for numerous purposes takes place the culture of specific place gets varied with the culture of another place. There comes the concept of liminality or nowhereness inviting the need of negation. Neither is fully represented in the people's space where the community occurs because of migration. The idea of fixed home has been challenged by the migration of people. The moving of people from one country to another threatens the notion of the real home or the original home and it is associated with the emotional closeness, the security and the warmth. This very idea is also in question when the tendency of people grows to be the multinational one.

There is confusion in one's identity the fixed identity is often challenged. It is replaced by new identity which is in dilemma and which is not properly welcomed in the host society.

The identity of the diaspora is at the crossroad. It is in the state of stiffness. This stiffness is caused because of cultural clash which can be defined in terms of cultural shock. And it ultimately makes the diaspora realize that they have not been completely accepted, as Safran believes, "certainty that their acceptance by the host society is impossible" (86). What can be said is the feelings and experiences, because of the cultural contrast one has to face, are of mixed type. Some of the feelings in the newer land, too, might be unhappy or of new experiences type while others are melancholic.

Rani, the main character in Sunil Bhatia's novel, American Karma, exposes her melancholic experiences and the state of her identity being at crossroad. She has to undergo through waves of discrimination in her position of associate director. She has faced direct racism, personal humiliation and rejection. She has even been refused accommodation in a motel because the motel owner that thinks that she is black or Hispanic. Rani recalls:

The motel receptionist thought Rani was Hispanic and told her to go "two block down. And there is a black guy who owns inn". After being told to look 
elsewhere, Rani remained the woman in the reception desk that there was a vacancy sign outside the motel. (101)

The natives deny diasporas' prestigious presence and their honorable identity among the host societies. They call them outsiders, inferiors and subordinate to the majority Whites. For this reason, Rani was not given accommodation in the motel. This short of discriminations behavior of the occident doesn't only shock the diasporas but also incite them, as Stephen Dufoix believes, to involve in sometimes unlawful activities. R. Radhakrishnan cites the examples of his son who is in deep indignation and frustration because his native friends, teachers and coaches mispronounce his name. He narrates to his friends stories from Ramayan and Mahabharat rather than the American culture and literature. Radhakrishnan writes:

My eleven year old son asks me, Am I Indian or American". The question excites me, and I think of the not too- distant future . . . and many others who have agonized over the question of identity through their multivalent narrative. I tell him he is both and offer him brief and down- to -earth definitions of ethnicity and how it relates to nationality and citizenship ... I am persuaded, for I have seen him express deep indignation and frustration when friends, peers, teachers, and coaches mispronounce his name in cavalier fashion. He pursues the matter with a passion bordering on the pedagogical, until his name echoes out correctly on alien lips, has also heard him narrate to his "mainstream" friends stories from the Ramayana and the Mahabharatha with an infectious enthusiasm for local detail...(203)

This expression of sadness of Indian diaspora, who feels his identity at a risk, is an evidence about the appalling condition of the Indian origin's people in America. Despite their birth in America, many Indian origin feel being othered, isolated and nowhere.

Bhatia brings forth a painful example of cultural assault when his protagonist Rani is expelled to play down the Indian culture. She wants to wear Indian sari and go to her office that matches her Indian culture. But the supervisor asks her promptly to go back home and change into Western dress:

My supervisor gave me a very sad time. And then he is going to write a report about in and, yes, yes, I was not allowed to wear sari. And actually he almost told me, since my home was not very far, "Go home and change" ? So, since that time I never wore Sari. (152).

The sorts of incidents were very common in the host land when the identity of diaspora was undermined and disgraced. The sari is a cultural symbol of difference and also an important part of Rani's dialogical self. To Rani, her supervisor's order - to go back home and get her dress changed is a move to neutralize her difference.

The management of otherness also means suppression of a voice that is an important component to Rani's cultural identity. By asking Rani to change her ethnic outfit, the supervisor wanted to play down Rani's Indianans or the voice that constructs the plurality of Rani's dialogical self.

Many people believe that people leave their country because she is not able to provide necessary facilities: education and economic advantages to her people. Had it been a good place, the people 
wouldn't leave their home. The logic sounds powerful to some extent. But, there is other side, that is, grim and unpleasant equally. It is not the true meaning and interpretation of aphorism when Lord Rama says, after he gets victory over Ravan, the king of Lanka:

\section{Apiswornā mayi Lānka name laxmana rhochate Janāni Janmā Bhumishā sworgadap Gariyasi \\ The Ramayan \\ (Laxmana, even this gold doesn't appeal to me; mother and motherland are greater than heaven).}

The loneliness and sadness of Ram and Laxmana is poignantly evoked in this epigraph. Despite becoming the lord of Lanka and its tempting richness, Ram and Laxmana feel as if they are isolated, dislocated and their identity may be at a stake ultimately in the alien land. Therefore, they long to return their home, their mother and motherland. Such evocation of painful feelings are common in the characters of the diasporic novels. Similarly, the host land may not be a good place from the cultural point of view, though good for education and financial perspectives. Thus, it can be said that no place is completely an ideal place. Prima facie, a person's central concern in the life is his/her identity. But these days, the days of globalization, people see the identity in different lights. The people who have migrated from one place to another want their ethnic identity first, then their gender identity and finally comes the matter of individual identity.

The collectivity in the land is the main need of the group. Patrick Taylor believes that identity involves both personal and that the collectivity dimension of identity takes psychological precedence over personal identity (23). Although the identity of a person at times is more important for him. The case of diaspora in the migrated land is seen differently. There the people's group identity comes first, in that, there is the confrontation with another group which could possibly be the group of the host land and which has not recognized the identity of the hosts. They often ask about the nationality of the hosts and the time they(the hosts) are going to spend in the USA. Bhatia agrees:

Shalini comments how her co-workers try to locate her in a bounded category of otherness based on us versus them, outsiders-insiders and majority minority divisions. Although Shalini has been in the United States for more than thirty years, she is still identified as a foreigner. In Shalini's voice these questions are not friendly queries that are asked as a means of developing friendship ... But Shalini feels that the questions, "Where are you from?" usually meant to place her in the social context of foreigner. The statement, "You are not from here" leads to the questions "why did you come here?."(69)

As a non White Indian, Shalini experiences feelings of otherness, marginalized and excluded in the large White majority culture. As marginality is a shifting concept because the central periphery, relationship is made up of over lapping circles in which one can be close to the central but still far away from it. Shalini, too, has similar feelings of being far away from the core.

In a similar vein Venkat, a character in Racism and Glass Ceiling, exposes his uneasiness in the diasporic state. Despite his sound academic performance, hard work and successful career, he has 
not been able to get success in this work not because of other reasons but because he is an Indian origin. He narrates

Venkat is the same man who mentioned that he was seen as Indian and therefore different by many of his coworkers that his being a foreign and having an accent would prevent him from achieving his potential in corporate America. (15).

It is therefore, important to analyze the feelings and experiences of the diaspora while they are in the host land. This is the case when people are away from their homeland and as they feel they are not isolated and in a state of nowhereness. So, identity becomes a matter of contestation.

The identity of diaspora is often challenged and their culture and civilization is contrasted. There historical experiences, the saga of their struggle for a respectable place in their new home is undermined. Then the diaspora understand that their identity is at crossroad.

Diaspora has to undergo with number of problems. Some of the problems are so severe that they lose their total identity by assimilating themselves. Their faith, their culture, language and convictions have been challenged. Ajay Dubey in Indian Diaspora writers:

In the French West Indies, Indian lost their identity. This happened because of the policy of assimilation followed by the French government policy. This policy assumed that all colonial subjects are capable of becoming completely like Frenchmen and adopted the policy of making every residents behave like French. This policy of assimilation ended to loss of language, culture and values of religions over a period of time. The identity of Indian workers got merged within the dominant culture, monoculture.

Indians' hard struggle to retain their identity was shattered. They had to adopt new culture, conviction and speak new French language. Their small number and they ruthless assimilation policy of French over a period of time suppressed their urge for their roots and identity.

Links with the 'homeland' and associated myths of 'origin' often play a large part in identity formation among migration communities. This process of identity formation whether culturally or linguistically is threatened. The host communities and the colonizers try to keep the migrant communities in their grip so that the migrant do not look for their new and separate identity, but get assimilated totally in the new culture which ultimately satisfies them. Frantz Fanon assumes:

Colonization is not only satisfied merely with holding people in its grip and emptying the natives brain of all form and content. By a kind of perverted logic, it turns to the past of oppressed people and distorts, disfigures and destroys it. (170)

It pictures the colonizers' attitude to the colonized. The desire of retaining the position of self and the creation of othering has occupied the mind of the Westerns.

The Indian accent becomes the cause of the creation of self and other. Because of their different intonation, and pronunciation of certain words, Indians are easily identified. Apart from their visible ethnicity, Indians' skin, hair colour and non-verbal behavior convey specific meaning of difference that exposes their foreignness and sense of otherness in the United States and Europe. 
Bhatia's characters Deepali feels such differences in her daughter's school because of her Indian accent. She retorts

As an Indian immigrant living in America, I feel different because of my pronunciations and my colour. These two things, you stand out immediately, and then the minute you open your mouth, those two things, but other than the there is rarely no reason ... (132)

On the first sight in seems that Indian make better living and better outcome in America. Nonetheless, they encounter number of problems. They feel culturally and linguistically isolated, feel difference in the host land.

Ethnicity is a state of consciousness in which people, who maintain their own customary way or culture, set themselves apart from others. In a broad sense, ethnicity takes shape on the basis of certain characteristics such as a language, religion, believes, race, castle and other common cultural traditions which are the major component of identity and which differentiate a particular group from others. A sense of otherness and a positive desire for a distinguishing identification are the distinct of a self aware ethnicity. However, this distinct feature of identification is opaque (not transparent) and questionable.

Stuart Hall retorts:

Identity is not as transparent or unproblematic as we think. Perhaps instead of thinking of identity as an already accomplished fact, which are new cultural practices then represent, we should think, instead of identity as a production which is never complete, always in process and always constituted' within, not outside, representation. This view problematizes the very authority and authenticity to which the term cultural identity" has claim.(77)

So, identities are those which are produced and reproduced themselves again and again through transformation and difference. They are diverse and complex.

The process of seeking identity is sometimes confronted by several sociocultural, political and economic forces. It takes a reverse turn when many ethnic tribes are forced to lose their citizenship and become refugee, take shelter in the neighboring countries. Rup Kumar Burman, in Ethnic Mosaic and cultural Nationalism writes that the ethnic Bhupalis (Butani Nepalis) were forced to leave their country while they were searching their identity.

... a large number of genuine Bhutanese particularly the Bhutanese -Nepalse (called Bhupalis lost their citizenship. Many of these Bhutanese Nepalese took shelter as refugees in the United Nations High Commission for Refugee (UNHCR) camps as immigrants both in Nepal and Indo-Bhutan borderland. (55).

The Bhupalis became the victim of discriminatory policies of the state though they have been living there for more than five centuries, occupying second position of 35 percentage, second to ruling class. They were exiled when refused to accept pluralism, multiculturalism and polyphony and declared one language, one culture and one nation policy in 1980. As claimed by Burman the genuine Bhutanese became the sufferer of Ngalongs' ruling elites' brutality. 
Therefore, identity as Hall says, is a vague, complicated and ambiguous term which needs a great deal of debate and discussion. On top of that the diasporic identity is opaque and polemic that need to draw the concern of different government and the people.

As people become transnational migrants and as ideas travel in cyber space, old notions of identity and negotiation that have been rooted to particular geographical places and parochial interest and challenged and redefined to reflect a new realities. In such a situation, Rani's expression of uneasiness in the host land deserve significant meaning. Besides, globalization has not only given the opportunities of trade and commerce but also has narrowed down the way of thinking and working of people. Therefore, globalization should address fundamental reorientation of traditional identities to take note of one's embeddedness in a worldwide contexts which many of the host lands have failed to entertain.

The view of identity and belongingness is fluid and constructed and at the same time it raises questions about the idea of nationalism in a changing world where one in every thirty five persons is an international migrants. So, what identity is. Is it an awareness of one's fluidity and constructedness. The appropriate buzzword in the present circumstances is "identity bricolage" which lights human agency in shaping and adopting individual identity

In his classical work, Imagined communities', Benedict Anderson defines nation as an imagined political community. His concept of imagined communities examines the complex process through which individual becomes attached to other communities and nation and through which identities emerges from sociability, how community members feel connected by developing shared identities.

One of the recurring themes in Mikhail Bhaktin's work is related to the construction of self-other relationships, society and the individuals forces that unify or divide the group, the institution or the society. Bakhtin, in problems of Dostoevsky's poetics believes that the dialogic battle is between the centripetal and centrifugal forces of language and life. As the centripetal forces unites and impose norms, regulation and the monological discourse of dominant social groups while the centrifugal forces interrupt the unifying forces of language. Bakhtin writes:

The centrifugal forces are the forces of hetroglossia that stratify and offer multiple fragmentary and decentralized views of the world. The Indian accent and her friends are a great part of the centrifugal forces of everyday life that cause small interpretations and ripples in the normative centripetal forces. The accustomed habit of Indians who long to follow Indian culture and their accent ultimately leaves them in trouble in confusion and at crossroad in America and elsewhere (cited in America Karma, 157).

The 'identity bricolage' provides a useful metaphor for building Benedict Anderson imagined communities and exploring how the interaction between subjectivity, institution and structure facilitate and constrain the imaginative process of building process of building not only a nation but also identity. Eric Kolig Samwong and other believe that identity politics redefine the concept and shape of citizenship and pose their own challenge to monochromatic nationalism policies of assimilation have been abandoned in favour of the right to maintain an choose the right to maintain and choose one's ethnic and culture identity. (18). 
In this age of globalization, therefore, any country whether USA, Europe or Asia must celebrate pluralism. They must preserve the identity, culture, language and religious of the minorities, lest, the vain effort of the West or Europe to preserve a national identity and sometime to create a new identity might lead to problems

\section{Conclusion}

Identify is no doubt a complex problem for any multi-ethnic, pluralistic and multicultural society. This problem originates mainly from the question of subordination of minority communities by the majority. Identity in the case of American Karma and other texts used as reference here reflect the cultural identity of the majority Whites in which smaller communities may be Indians, Nepalese and other ethnic groups have little place. Imposition of the white identity over minorities has led to dissatisfaction, confusion, ethnic unrest and above all the identity of the minority is at the crossroad.

Cultural pluralities and ethnic identities have been lost, submerged and almost eradicated. Rights of minorities have been challenged to ensure homogeneity. For example, Driglam Namzha, means one language, one culture and one religion in Bhutan.

Previously marginalized and culturally suppressed groups assert themselves their identity. Identities without the incorporation of minorities are sure to be weak and fragmented policies of assimilation have been introduced as in France; ethnic and cultural identity and various form of life styles have been regarded into tolerable, classical imperative: when you live in Rome do as Roman do (18) is enforced. Hence, identity at crossroad.

\section{Works Cited}

Aranyakanda. The Ramayan. India.

Anderson, Benedict. Imagined Communities: Reflections on the Origin and Spread of Nationalism. Verso, 1983.

Barman, Rup Kumar, "Ethnic Mosaic and the Cultural Nationalism of Bhutan", Identity in Crossroad Civilization. Ed. Erich Kolig, Vivienne SM, Angeles and Sam Wong. Amsterdam UP, 2009, pp. 55-64.

Bhatia, Sunil. American Karma: Race, Culture and Identity in the Indian, Diaspora. New York UP, 2007.

Dubey, Ajaya. "Indian Diaspora in the Caribbean and Africa. Identities Issues and Responses of Indian". Indian Diaspora. Kalinga Publications, 2003, pp. 117-47.

Dufoix, Stephen. Diasporas, University of California P, 2008.

Edgar, Andrew and Peter Sedgwick eds. Key concepts in Cultural Theory. Rutledge, 1999.

Fanon, Frantz. "On National Culture". The Wretched of the Earth. OUP, 1963, p. 170.

Fornas, John. Cultural Theory and Late Modernity, SAGE Publication, 1995.

Hall, Stuart. "Cultural Identity and Diaspora". Contemporary Post-colonial Theory. Edited by Padmini Mongia OUP, 1997, pp. 110-20. 
Kolig, Erich, Vivienne, Sam Wong, et al. "Introduction: Cross Civilization and Bricolage Identities" Identity in Cross Road Civilization Amsterdam UP, 2009, pp.9-20.

Mishra, Vijaya. "Introduction: The Diasporic Imaginary". The Literature of Indian Diaspora. Rutledge, 2007-1.

Radhakrishnan, Rajogopalan, "Is the Ethnic Authentic' in the Diaspora" Diasporic Mediations: Between Home and Location. University of Minnesota P, 1997, pp.203-4.

Safran, William. "Diaspora in Modern Societies: Myth of Homeland and Return". Diaspora, 11 (1991): 83-99.

Taylor, Patrick. Only Wounded Stories of the Irish Trouble. Forge Book, 2015.

West, Cornel. "A Matter of Life and Death", The Identity in Question. Ed. John Rajchman. Harvester Wheat Sheaf, 1993. 